\title{
PEMBENTUKAN HUKUM DALAM PERSPEKTIF PEMBARUAN HUKUM
}

\author{
(Law Making on the Perspective of Legal Reformation) \\ Zainal Arifin Hoesein \\ Fakultas Hukum Universitas Sebelas Maret, Surakarta \\ JI. Ir. Sutami 36 A Surakarta, Surakarta 57126 \\ Email: arifinhoesein55@yahoo.com
}

Naskah diterima: 12 Desember 2012; revisi: 15 Desember 2012; disetujui: 17 Desember 2012

\begin{abstract}
Abstrak
Materi muatan hukum selayaknya mampu menangkap aspirasi masyarakat yang tumbuh dan berkembang bukan hanya yang bersifat kekinian, melainkan sebagai acuan dalam mengantisipasi perkembangan sosial, ekonomi, budaya dan politik di masa depan. Norma hukum pada dasarnya inheren dengan nilai-nilai yang diyakini oleh masyarakat, tetapi daya kekuatan keberlakuan hukum, tidak dapat melepaskan diri dari kelembagaan kekuasaan, sehingga hukum, masyarakat dan kekuasaan merupakan unsur dari suatu tatanan masyarakat. Oleh karena itu, Hukum tidak sekedar dipahami sebagai norma yang menjamin kepasatian dan keadilan tetapi juga harus dilihat dari perspektif kemanfaatan. Oleh karena itu, maka pembentukan hukum dalam perspektif pembaruan hukum harus difokuskan pada dua hal yaitu, sistem hukum dan budaya hukum. Tulisan ini akan membahas bagaimana idealisasi peraturan perundang-undangan; bagaimana fungsi peraturan perundang-undangan dalam pembangunan hukum; dan bagaimana pendekatan metodologis terhadap pembentukan hukum. Dari berbagai pembahasan tersebut disimpulkan bahwa pembentukan hukum dalam perspektif pembaharuan hukum, di samping harus memperhatikan aspek metodologis, juga harus merujuk dan meletakkan norma hukum dalam kesatuan harmoni vertikal dengan aspek teologis, ontologis, positivistik dan aspek fungsional dari suatu norma hukum. Kata kunci: aspirasi, budaya, sistem hukum, pembaharuan, pembentukan, metodologi
\end{abstract}

\begin{abstract}
The substance of the law should be able to capture the aspirations of the people who grow and develop not only be present, but as a reference in anticipation of the social, economic, cultural and political future. The rule of law is essentially inherent to the values that are believed by the public, but the validity of the power of the law, not to break away from the institutional power, so the law, society and power is an element of a society. Therefore, the law does not merely understood as a norm that ensures certainty and justice but also to be seen from the perspective of expediency. Therefore, the legal establishment in the perspective of legal reform should be focused on two things, namely, the legal system and legal culture. This paper will discuss how the idealization of laws, how the laws function in the development of the law, and how the methodological approach to the legal establishment. It was concluded that the formation of the law in the perspective of legal reform, in addition must pay attention to methodological aspects, should also refer to and put the rule of law in the unity of vertical harmony with aspects of the theological, ontological, positivist and functional aspects of the rule of law.
\end{abstract}

Keywords: aspirations, culture, legal system, reformation, development, the methodologies 


\section{A. Pendahuluan ${ }^{1}$}

Secara sosiologis, hukum merupakan refleksi dari tata nilai yang diyakini masyarakat sebagai suatu pranata dalam kehidupan pribadi, bermasyarakat, berbangsa dan bernegara. Dalam perspektif ini, maka hukum dapat dijadikan sebagai acuan pembaruan masyarakat sebagaimana konsep Roscoe Pound tentang, law as a tool of social engeneering. ${ }^{2}$ Materi muatan hukum selayaknya mampu menangkap aspirasi masyarakatyang tumbuh dan berkembang bukan hanya yang bersifat kekinian, melainkan sebagai acuan dalam mengantisipasi perkembangan sosial, ekonomi, budaya dan politik di masa depan. Pemikiran tersebut menunjukkan bahwa hukum bukan sekedar norma statis yang mengutamakan kepastian dan ketertiban, tetapi merupakan norma-norma yang harus mampu mendinamisasi pemikiran dan merekayasa perilaku masyarakat dalam mencapai citacitanya. ${ }^{3}$ Pandangan ini menunjukkan bahwa norma hukum pada dasarnya inheren dengan nilai-nilai yang diyakini oleh masyarakat, tetapi daya kekuatan keberlakuan hukum, tidak dapat melepaskan diri dari kelembagaan kekuasaan, sehingga hukum, masyarakat dan kekuasaan merupakan unsur dari suatu tatanan masyarakat. Oleh karena itu, Hukum tidak sekedar dipahami sebagai norma yang menjamin kepasatian dan keadilan tetapi juga harus dilihat dari perspektif kemanfaatan. ${ }^{4}$ Posisi hukum menjadi persoalan ketika berada pada situasi transisi sistem kekuasaan pemerintahan yang otoritarian menuju sistem demokrasi seperti yang dialami Indonesia saat ini. Indonesia merupakan salah satu negara terbesar yang tengah mengalami proses perubahan dari rezim otoritarian kearah demokrasi. Kendatipun demikian, perubahan yang terjadi tidak serta merta menghasilkan rezim demokratik. Terdapat satu interval waktu antara hancurnya rezim otoritarian dengan terbentuknya rezim baru yang solid yang ditandai oleh berbagai ketidakpastian yang disebut dengan masa transisi. ${ }^{5} \quad$ Ketidakpastian dalam masa transisi menyebabkan tidak menentunya norma hukum dalam berbagai kehidupan. Hal ini terjadi bukan hanya karena berbagai norma hukum dalam berbagai kehidupan tersebut bekerja dalam situasi perubahan yang terus menerus, tetapi juga karena biasanya norma hukum tersebut dipertarungkan dalam suatu kompetisi politik yang sengit. ${ }^{6}$ Dari aspek hukum, situasi ketidakpastian dalam masa transisi mengindikasikan tidak berjalannya proses-proses hukum yang bersifat stabil dan otonom. Proses hukum beroperasi di tengah

$1 \quad$ Artikel ini pernah disampaikan dalam Continuing Legal Education (CLE) tentang Penggunaan Metode RIA dan ROCCIPI dalam Penelitian dan Pembentukan Hukum, diselenggarakan Badan Pembinaan Hukum Nasional, Jakarta, 12 Desember 2012.

2 Roscoe pound, An Introduction to the Philosophy of Law - with a new introduction by Marshal L. De Rosa, (New Brunswick (USA) and London (UK), 1999 - Originally published in 1922 by Yale University Press), hlm. 4.

3 Bagir Manan, Menegakkan Hukum Suatu Pencarian, Cetakan Pertama (Jakarta: Asosiasi Advokat Indonesia, 2009), hal. 164 - 165. Lihat pendapat David N. Schiff, Hukum Sebagai Suatu Fenomena Sosial, dalam Adam Podgorecki dan Christopher J. Welan(editor), Pendekatan Sosiologis Terhadap Hukum, terj. dari , Sociological Approaches To Law, ( Jakarta: Bina Aksara, 1999), hlm. 252-254

4 John Rawl, Teori Keadilan, Dasar-Dasar Filsafat Politik untuk Mewujudkan Kesejahteraan Sosial dalam Negara, (Yogyakarta: Pustaka Pelajar, 2006), hal. 513-517, terjemahan A Theory of Justice, (Cumbride, Massachusett: Harvard University Press: 1995).

5 Deliar Noer, Partisipasi Dalam Pembangunan, (Kuala Lumpur: Angkatan Belia Islam Malaysia, 1977), hlm. 55.

6 Guillermo O’Donnel dan Phlippe C. Schmitter, op.cit., hlm. 6-7. 


\section{$\mathrm{R}_{\text {juknaL }}^{\text {juTSVINDING }}$

perubahan yang terus menerus dan dipengaruhi oleh konflik di antara para pelaku politik. Dalam situasi seperti ini fungsi hukum yang dapat diproyeksikan secara sosiologis adalah sebagai instrumen pengendali dan pemandu perubahan sosial serta sebagai mekanisme integratif dalam mengelola berbagai konflik sosial yang terjadi. Pada saat perubahan sosial politik yang terjadi di masa transisi, hukum dapat difungsikan untuk mengontrol dan memandu perubahan tersebut ke arah terbentuknya rezim demokratik yang solid.

Dalamperspektifini, makahukum difungsikan sebagai instrumen bagi perubahan sosial ke arah kondisi sosial tertentu. Dalam situasi konflik tersebut hukum seringkali menjadi mandul dan kehilangan relevansi. Konflik sosial dalam situasi seperti ini lebih sering memunculkan mekanisme penyelesaian melalui kekerasan yang akhirnya mengakibatkan disintegrasi sosial yang parah. Problem hukum yang muncul berkenaan dengan fungsi-fungsi hukum di era transisi tersebut adalah kontekstualitas hukum dengan situasi transisi pada negara berkembang seperti Indonesia. Fungsi-fungsi hukum yang diuraikan di atas merupakan kajian terhadap hukum pada masyarakat yang memilki karakteristik impersonal, otonom, dan rasional. Dalam kaitan ini, fungsi hukum sebagai instrumen perubahan sosial dibangun berdasarkan asumsi hukum sebagai "an agency of power; an instrument of goverment." ${ }^{\prime 7} \mathrm{Hal}$ Ini berarti negara memilki otoritas yang kuat untuk menggerakkan perubahan melalui instrumen hukum. Problematiknya dalam konteks masa transisi di Indonesia, hukum bekerja di tengah perubahan drastis dan konflik yang sengit antara kekuatan-kekuatan politik. Dalam situasi seperti itu, sulit diperoleh adanya otoritas yang kuat dan legitimatif bagi penggunaan hukum sebagai instrumen perubahan sosial. Bukan saja otoritas pemerintahan menjadi lemah, tetapi juga tidak memiliki legitimasi yang kuat di hadapan masyarakat, baik lembaga eksekutif, legislatif maupun yudisial mengalami proses delegitimasi di hadapan masyarakat. Hal ini mengakibatkan ketidakefektifan penegakan hukum di tengah masyarakat dewasa ini yang sering ditandai oleh terjadinya penggunaan kekerasan dan main hakim sendiri dalam penyelesaian berbagai konflik sosial. Dalam konteks ini hukum tidak dapat berfungsi semestinya sebagai mekanisme integratif dan pengelola konflik sosial. ${ }^{8}$

Oleh karena itu, maka pembentukan hukum dalam perspektif pembaruan hukum harus difokuskan pada dua hal yaitu, sistem hukum dan kultur/budaya hukum. Sistem hukum meliputi materi hukum, kelembagaan hukum, sarana dan prasarana, sumber daya manusia di bidang hukum, dan manajemen hukum/yustisial. Sedangkan kultur/budaya hukum berkaitan dengan budaya berhukum bagi penyelenggara negara termasuk didalamnya penegak hukum dan masyarakat. Dalam hubungan ini seluruh konflik baik antara negara dengan warga negara, antar lembaga-lembaga negara, maupun antar warga negara melalui mekanisme hukum. Sebab, perubahan yang terjadi, jika tidak dikendalikan melalui mekanisme hukum yang berwibawa, maka konflik tersebut kemungkinan berdampak pada kerusakan sosial yang dahsyat.

Roger Cotterell, The Sociology of Law: An Introduction, (London: Butterworths, 1992), hlm. 44.

$8 \quad$ Ibid, hlm. 45. 
Dalam pandangan Hans Kelsen, ${ }^{9}$ hukum adalah suatu hierarki mengenai hubungan normatif, bukan suatu hubungan sebab akibat dan esensinya adalah terletak pada "yang seharusnya ada (ought)" dan "yang ada (is)" (Sollen und sein). ${ }^{10}$ Oleh karena itu, kajian Kelsen tentang hukum adalah norma hukum (the legal norm), elemen-elemennya, interelasinya, tatanan hukum secara keseluruhan strukturnya, hubungan tatanan hukum yang berbeda, dan kesatuan hukum dalam tatanan hukum positif yang majemuk. Realitas hukum adalah suatu fenomena yang lebih banyak dirancang sebagai "the positiveness of law", dan dalam hal ini Kelsen membedakan dengan jelas antara "emperical law and transcedental justice by excluding the letter from specific concerns." ${ }^{11}$

Hukum bukan manifestasi dari suatu "superhuman authorithy", tetapi merupakan suatu teknik sosial berdasarkan pengalaman manusia. Konsekuensinya, dasar suatu hukum atau "validitasnya" bukan dalam prinsipprinsip meta juristik, tetapi dalam suatu hepotesis juristik, yakni suatu norma dasar yang ditetapkan oleh "a logical analaysis of actual juristic thinking". Dengan demikian, Kelsen tidak berbicara tentang hukum sebagai kenyataan dalam praktek, tetapi hukum sebagai disiplin ilmu, yakni apa yang terjadi dengan hukum dalam praktek berbeda dengan apa yang dipelajari dalam ilmu hukum, yang hanya mempelajari norma-norma hukum positif bukan aspek-aspek etis, politis, atau sosiologis yang dapat muncul dalam praktek hukum. ${ }^{12}$

Sebagaimana diuraikan di atas, bahwa nilai validitas suatu hukum terletak pada kesesuainnya dengan norma lainnya terutama norma dasar. Dalam hubungan ini dapat dijelaskan bahwa norma dasar dapat dibedakan menjadi dua yaitu, norma statis dan norma dinamis. Norma statis merupakan norma yang telah memiliki validitas, sehingga seluruh isi norma tersebut ditaati dan diterapkan dalam kehidupan individu dan sosial. Setiap isi norma tersebut memiliki daya pengikat dan daya paksa, karena berasal dari norma dasar yang spesifik, memiliki validitas yang diyakini dan dipandang sebagai norma yang paling tinggi (akhir). Sifat statis, karena norma tersebut memiliki pengertian umum yang dapat dijadikan dalam membentuk norma khusus.Sedangkan norma dinamis, merupakan pembentukan norma dasar tertentu karena tidak ditemukan dalam norma statis, karena adanya perkembangan sosial,

\footnotetext{
Hans Kelsen, General Theory Theory of Law and State, (New York: Russell \& Russell, 1945), hlm. 124.

10 Ibid, hlm. 120. Lihat W. Friedmann, Legal Theory, Fifth Edition (New York: Columbia University Press, 1967), hal. $275-276 " . .$. the science of law is hirarchy of normative relations, not a squence of causes and effect. ..... the most important foundation of Kelsen's theory, is essentially Neo Kantian, in so far as Kan had made the fundamental distinction between man as part of nature - subject to the laws of causation - and as a reasenable being wich regulates its conduct by imperative. This Produces the essential difference between "Ought" and "Is" (sollen und sein).

11 Hans Kelsen, Pure Theory of Law, (Berkeley, Los Angeles, London: University of California Press, 1978), hlm. xiii - xiv. Hal senada juga diuraikan oleh Joseph Raz, The Concept of a Legal System, Oxford: Oxford University Press, 1970).

12 Ibid, hlm. $5 \ldots$... selanjutnya Kelsen menjelaskan bahwa: „.... The problem of law, as scientific problem, is the problem of social technique, not a problem of morals. The statement: "A certain social order has the character of law, is a legal order", does not imply the moral judgment that this order is good or just. There are legal orders wich are, from a certain point of view, unjust. Law and justice are two different concepts. Law is distinguished from justice is positive law. It is the concept of positive law wich is here in question; and a science of positive law must be clearly distinguished from a philosophy of justice.
} 


\section{$\mathrm{R}_{\text {juknaL }}^{\text {juTSVINDING }}$ \\ Media Pembinaan Hukum Nasional}

Volume 1 Nomor 3, Desember 2012

tetapi tidak dikaitkan dengan realitas sosial. Jika perkembangan sosial memiliki kehendak untuk mewujudkan suatu norma baru, maka pembentukannya tetap didasarkan pada norma dasar. ${ }^{13} \mathrm{Hal}$ ini berarti otoritas pembentukannya sesuai dengan ketentuan yang tercantum dalam norma dasar tersebut. Suatu norma merupakan bagian dari suatu sistem yang dinamis, jika norma tersebut telah dibuat menurut cara yang ditentukan oleh norma dasar. Deskripsi di atas menujukkan bahwa suatu norma hukum itu valid, karena dibuat menurut cara yang ditentukan oleh suatu norma hukum lainnya, dan norma hukum lainnya adalah landasan validitas norma hukum tersebut. Hubungan antara norma hukum yang mengatur pembentukan norma lain dengan norma lainnya sebagai hubungan antara "superordinasi" dengan "subordinasi" atau "superior dengan inferior norm" yang menunjukkan level atau hierarki norma. Norma yang menentukan pembentukan norma lainnya adalah norma yang lebih tinggi derajatnya, begitu sebaliknya, norma yang dibentuk tersebut derajatnya lebih rendah. Dalam hubungan ini, maka hubungan antara norma yang lebih tinggi dengan norma di bawahnya merupakan hubungan hierarki norma. Konsekuensinya adalah, bahwa norma yang lebih rendah derajatnya tidak dibenarkan bertentangan dengan norma di atasnya.

Dengan demikian, suatu kesatuan hukum merupakan rangkaian hubungan hierarkis antara norma-norma yang satu dengan lainnya secara hierarkis tidak boleh bertentangan.
Norma sebagai kesatuan nilai yang hidup dalam masyarakat memiliki kekuatan memaksa, dan ditaati, ketika norma tersebut telah ditempatkan sebagai pernyataan kehehendak, baik pernyataan kehendak individu maupun penyataan kehendak pembuat undang-undang. Penyataan kehendak tersebut diwujudkan baik dalam bentuk suatu transaksi hukum maupun dalam suatu undang-undang yang didalamnya mengandung unsur perintah atau keharusan untuk ditaati (validitas) dan diterapkan (efektifitas). Hal ini menujukkan bahwa setiap norma hukum memiliki unsur paksa, baik pada sisi pentaatan, maupun sisi penerapannya, dan untuk ini diperkenalkan unsur sanksi. Makna validitas norma hukum adalah bahwa setiap materi muatan norma hukum memiliki daya ikat dan paksa bagi subyek hukum tertentu dalam melakukan setiap perbuatan hukum. Sedangkan efektifitas norma hukum, berarti segi penerapan materi muatan hukum oleh organ yang memiliki otoritas untuk menerapkan suatu norma hukum. Jika terjadi suatu kasus pelanggaran terhadap suatu norma hukum, dan organ tersebut tidak mampu memberikan sanksi, maka norma hukum tersebut dapat dikatakan tidak efektif. Oleh karena itu, menurut Kelsen validitas dan efektifitas hukum merupakan dua hal yang berbeda, yaitu validitas lebih bermuatan pada segi normatif, dan efektifitas lebih kepada proses penerapan norma.

Landasan validitas suatu norma selalu dari norma, dan bukan dari fakta. Pencarian landasan validitas suatu norma bukan dari realita

13 Hans Nawiasky, Allgemeine Rechtslehre als System der rechtlichen Grundbegriffe, cet. kedua (Einsiedeln/Zurich/ Koln: Benziger, 1948), hal.31 sebagaimana yang dikutip oleh A. Hamid Attamimi dalam, Peranan Keputusan Presiden Republik Indonesia dalam Penyelenggaraan Pemerintahan Negara - Suatu Studi Analisis Mengenai Keputusan Presiden yang Berfungsi Pengaturan dalam Kurun Waktu Pelita I - Pelita IV, disertasi yang dipertahankan di hadapan Senat Guru Besar Universitas Indonesia tanggal 12 Desember 1990 di Universitas Indonesia, hlm. 288-289. 
melainkan dari norma lain yang menjadi sumber lahirnya norma tersebut. Oleh karena itu, suatu norma yang validitasnya hanya dapat diperoleh dari norma yang lebih tinggi, Kelsen menyebut "norma dasar". ${ }^{14}$ Norma dasar berfungsi sebagai rujukan dari setiap pembentukan norma, sehingga norma dasar juga sebagai sumber utama dan merupakan pengikat di antara norma-norma yang berbeda, dalam membentuk suatu tata normatif. Dalam pandangan ini, maka apabila suatu norma masuk dalam suatu tata norma tertentu, validitas atas norma tersebut dapat diuji oleh norma dasar tersebut. ${ }^{15}$ Aliran hukum positif yang dikembangkan oleh Hans Kelsen, juga dikembangkan oleh John Austin. Menurut Austin hukum adalah; " a rule laid down for the guidance of an intelligent being by an intelligent being having power over him"16 Pada prinsipnya hukum positif memberikan penegasan bahwa, pertama, suatu tata hukum negara berlaku karena mendapatkan bentuk positifnya dari institusi kekuasaan; kedua, hukum semata-mata dilihat dari bentuk formal, sehingga bentuk hukum formal dipisahkan dari bentuk hukum material; dan ketiga, isi hukum diakui ada, tetapi bukan sebagai bahan ilmu hukum.

Dengan demikian, hukum menurut Austin adalah sekumpulan perintah penguasa atau perintah dari pemegang kekuasaan (kedaulatan) untuk mengatur kehidupan masyarakat; hukum merupakan sistem logika yang bersifat tertutup atau terlepas dari moral, politik dan sosial; dan hukum harus memenuhi unsur perintah, sanksi, kewajiban dan kedaulatan. Oleh karena itu, bentuk hukum adalah undangundang, isi hukum adalah perintah penguasa, ciri hukum adalah sanksi, perintah, kewajiban, dan kedaulatan, dan sistemasi norma hukum. Hal ini menunjukkan bahwa pembentuk hukum adalah penguasa, bentuk hukum adalah undang-undang dan hukum diterapkan melalui pembebanan sanksi terhadap pelanggarnya. Walaupun Kelsen menolak dengan tegas adanya pencampuran antara hukum dan keadilan, tetapi dalam konteks pembentukan undangundang, tidaklah harus mengabaikan keadilan, ${ }^{17}$ karena keadilan merupakan bagian dari tujuan

14 Hans Kelsen, General Theory ... op. cit., hlm. 30 - 39-Bandingkan dengan Hans Nawiasky, sebagaimana yang dikutip oleh A. Hamid Attamimi dalam, Op.Cit., hlm. 287-288. Dalam kaitan ini, norma dasar oleh Hans Nawiasky diartikan sebagai 'staatsfundamentalnorm'atau oleh Notonagoro disebut'norma fundamental negara' yaitu, suatu norma yang merupakan dasar bagi pembentukan konstitusi dari suatu negara termasuk norma pengubahannya. Hakekat hukum suatu 'staats-fundamentalnorm' adalah syarat bagi berlakunya suatu konstitusi atau undangundang dasar. Oleh karena itu ,staatsfundamentalnorm' ada terlebih dahulu sebelum konstitusi atau undangundang dasar.

15 Ibid, hlm. 111. Bandingkan Hans Nawiasky dalam Hamid Attamimi, Op.Cit., hlm. 287 yang menjelaskan bahwa tata susunan norma dari atas ke bawah adalah: norma dasar fundamental negara (staatsfundamentalnorm); Aturan dasar negara/aturan pokok negara (staatsgrundgesetz); undang-undang (formal) (formell gesetz); dan peraturan pelaksanaan serta peraturan otonom (verordnung dan autonome satzung).

16 John Austin, Edited by Wilfrid E Rumble, The Province of Jurisprudence Determined, (New York: Cabridge Universuty Press, 1995) hal. 77. Lihat Hans Kelsen yang menekankan bahwa, pertama, hukum merupakan sistem norma (murni) yang terbebas anasir di luar hukum seperti politik, moral, dan sebagainya; kedua, hukum sebagai suatu keharusan (keharusan untuk ditaati); dan ketiga, hukum merupakan kesatuan sistem peringkat (norma). Hukum sebagai suatu sistem peringkat (norma) pada hakikatnya merupakan sistem hirarkhis yang tersusun dari peringkat yang terendah sampai peringkat tertinggi. Hukum yang lebih rendah harus berdasar dan tidak boleh bertentangan dengan hukum yang lebih tinggi. Hans Kelasen, General Theory .. Op.Cit, hlm. 71.

17 Hari Chand, Modern Jurisprudence, (Kuala Lumpur: International Law Book Services, 1994), hlm. 67. 


\section{$\mathrm{R}_{\text {juknaL }}^{\text {juTSVINDING }}$}

hukum. ${ }^{18}$ Pembaruan hukum merupakan upaya sadar, terencana dan

\section{B. Permasalahan}

Permasalahan yang akan dibahas dalam tulisan ini adalah:

1. Bagaimana idealisasi peraturan perundang-undangan?

2. Bagaimana fungsi peraturan perundangundangan dalam pembangunan hukum?

3. Bagaimana pendekatan metodologis terhadap pembentukan hukum?

\section{Metode Penelitian}

Berdasarkan indentifikasi masalah yang telah diuraikan di atas, maka tulisan ini masuk dalam ranah penelitian hukum normatif. Untuk itu tulisan ini mempergunakan penelitian yuridis normatif.

\section{Pembahasan}

\section{Idealisasi Peraturan Perundang- Undangan}

Secara konsepsional, Peraturan perundangundangan diartikan sebagai keputusan tertulis yang dikeluarkan pejabat atau lingkungan jabatan yang berwenang yang berisi aturan tingkah laku yang bersifat atau mengikat secara umum dimana aturan tingkah laku tersebut berisi ketentuan-ketentuan tentang hak, kewajiban, fungsi, status dan suatu tatanan. ${ }^{19}$ Di samping bersifat umum, maka hal-hal yang diatur juga bersifat abstrak. Oleh karena itu, sifat umum dan abstrak menjadi ciri atau elemen dari peraturan peundang-undangan. Sifat umum dan abstrak yang dilekatkan sebagai ciri peraturan perundang-undangan, dimaksudkan untuk membedakan dengan keputusan tertulis pejabat atau lingkungan jabatan yang berwenang yang bersifat individual dan kongkrit yakni 'ketetapan' atau 'beschikking'.

Peraturan perundang-undangan memiliki 3 (tiga) unsur penting, yaitu: a).Peraturan perundang-undangan berbentuk keputusan tertulis, sehingga dapat juga disebut hukum tertulis; b). Peraturan perundang-undangan dibentuk oleh pejabat atau lingkungan jabatan (badan, organ), yang memiliki wewenang membuat peraturan yang berlaku atau mengikat umum; dan c). Peraturan perundang-undangan bersifat mengikat secara umum. Sedangkan suatu keputusan itu dapat dikategorikan sebagai ' ketetapan' atau 'beshcikking' apabila memenuhi beberapa unsur, yaitu: a).keputusan sepihak; b).keputusan tersebut adalah tindakan hukum di lapangan hukum publik; c).keputusan dibuat oleh badan atau pejabat tata usaha negara; d) keputusan mengenai masalah atau keadaan kongkrit dan individual; dan e). keputusan dimaksudkan untuk mempunyai akibat hukum tertentu yaitu, menciptakan, mengubah, menghentikan, atau membatalkan suatu hubungan hukum. ${ }^{20}$ Dengan demikian, dapat dibedakan antara keputusan yang berbentuk peraturan perundang-undangan yang bersifat mengatur (regeling) dan mengikat secara umum dengan keputusan yang berbentuk beschikking. Dalam kaitan pengertian peraturan yang bersifat mengatur dan mengikat secara

18 Jeremy Bentham, The Theory of Legislation, (Bombay: NM.Tripathi Private Limited, 1979), hlm.2.

19 Bagir Manan, Dasar-Dasar Perundang-undangan Indonesia, (Jakarta: Indo Hill Co, 1992), hlm.3

20 Safri Nugaraha dkk, Hukum Administrasi Negara, (Jakarta: Badan Penerbit Fakultas Hukum UI, 2005), hlm. 77. 
umum dan ketetapan yang bersifat kongkrit dan individual. Batasan untuk membedakan pengertian 'regeling' dan 'beschikking', bahwa suatu putusan dapat dikatagorikan sebagai peraturan yang bersifat mengatur (regeling), pertama, kepentingan publik; kedua, menyangkut hubungan hukum atau hubungan hak dan kewajiban diantara sesama warga negara, dan antara warga negara dengan negara serta antara warga negara dengan pemerintah. Sedangkan beschikking merupakan keseluruhan 'ketetapan' adminsitratif yang dikeluarkan oleh pejabat publik yang dalam kapasitasnya diberikan kewenangan oleh UUD dan/atau UU untuk mengeluarkan ketetapan tentang sesuatu hal yang bersifat internal dan tidak bersifat publik, sehingga pengikatannya langsung kepada yang bersangkutan. ${ }^{21}$ Dalam arti khusus pengertian peraturan perundang-undangan adalah keseluruhan susunan hirarkis peraturan perundang-undangan yang berbentuk UndangUndang ke bawah, yaitu semua produk hukum yang melibatkan peran lembaga perwakilan rakyat bersama-sama dengan pemerintah ataupun melibatkan peran pemerintah karena kedudukan politiknya dalam rangka melaksanakan produk legislatif yang ditetapkan oleh lembaga perwakilan rakyat bersama-sama dengan pemerintah menurut tingkatannya masing-masing. Untuk menentukan apakah peraturan perundang-undangan tersebut masih berlaku atau tidak, maka terdapat beberapa istilahl yang terkait yaitu:

\section{- Dicabut:}

apabila undang-undang yang bersangkutan dicabut oleh undang-undang dan dinyatakan secara tegas dalam undang-undang yang mencabut. Maka akibat dari undang-undang yang dicabut adalah seluruh materi muatan undang-undangyang bersangkutan tidak berlaku sejak ditetapkan undang-undang penggantinya (legislative review)

\section{- Diubah:}

apabila sebagian materi suatu undangundang diubah kata/kalimat, atau ditambah materi dalam ayat atau pasal. Akibatnya, materi muatan yang diubah tidak berlaku dan yang berlaku adalah materi muatan pengubahnya atau penambahan, tetapi materi muatan undang-undang yang bersangkutan sepanjang yang tidak diubah atau ditambah tetap berlaku penuh.

\section{- Diadakan yang baru:}

Pembuatan undang-undang baru sesuai dengan kebutuhan sebagaimana lazimnya proses dan prosedur pembuatan undang-undang, baik lembaga pembuatnya, maupun prosedur pembuatannya. Kedua hal tersebut penting (lembaga pembuat dan prosedur), karena jika kedua hal tersebut cacat, maka suatu undangundang dapat dimintakan oleh masyarakat untuk diuji dan selanjutnya dimohonkan untuk dibatalkan.

21 Jimly Ashiddiqie, Konstitusional \& Konstitusionalisme Indonesia, (Jakarta: Mahkamah Konstitusi RI dan Pusat Studi Hukum Tata negara Fakultas hukum Universitas Indonesia, 2004), hlm. 250 -254. 


\section{REECHTSVINDING}

\section{Fungsi Peraturan Perundang- undangan}

\section{a. Fungsi Internal}

\section{1) Fungsi Penciptaan Hukum}

Penciptaan hukum (rechtschepping) yang melahirkan sistem kaidah hukum yang berlaku umum dilakukan atau terjadi melalui beberapa cara yaitu melalui putusan hakim (yurisprudensi), kebiasaan yang tumbuh sebagai praktek dalam kehidupan masyarakat atau negara, dan peraturan perundangundangan sebagai keputusan tertulis pejabat atau lingkungan jabatan yang berwenang yang berlaku secara umum. Secara tidak langsung, hukum dapat pula terbentuk melalui ajaranajaran hukum (doktrin) yang diterima dan digunakan dalam pembentukan hukum. Di Indonesia, peraturan perundang-undangan merupakan cara utama penciptaan hukum. Peraturan perundang-undangan merupakan sendi utama sistem hukum Nasional. Pemakain peraturan perundang-undangan sebagai sendi utama sistem hukum Nasional karena sistem hukum Indonesia - sebagai akibat sistem hukum Hindia Belanda - lebih menampakkan sistem hukum kontinental yang mengutamakan bentuk sistem hukum tertulis (geschrevenrecht, written law). Politik pembangunan hukum Nasional mengutamakan penggunaan peraturan perundang-undangan sebagai instrumen utama dibandingkan dengan hukum yurisprudensi dan hukum kebiasaan. Hal ini antara lain karena pembangunan hukum Nasional yang menggunakan peraturan perundang-undangan sebagai instrumen dapat disusun secara berencana (dapat direncanakan).

\section{2) Fungsi Pembaharuan Hukum}

Peraturan perundang-undangan merupakan instrumen yang efektif dalam pembaharuan hukum (law reform) dibandingkan dengan penggunaan hukum kebiasaan atau hukum yurisprudensi. Telah dikemukakan, pembentukan peraturan perundang-undangan dapat direncanakan sehingga pembaharuan hukum dapat pula direncanakan. Peraturan perundang-undangan tidak hanya melakukan fungsi pembaharuan terhadap peraturan perundang-undangan (yang sudah ada). Peraturan perundang-undangan dapat pula dipergunakan sebagai sarana memperbaharui yurisprudensi, hukum kebiasaan atau hukum adat. Fungsi pembaharuan terhadap peraturan perundang-undangan antara lain dalam rangka mengganti peraturan perundang-undangan dari masa pemerintahan Hindia Belanda. Tidak pula kalah pentingnya memperbaharui peraturan perundang-undangan nasional (dibuat setelah kemerdekaan) yang tidak sesuai lagi dengan kebutuhan dan perkembangan baru. Di bidang hukum kebiasaan atau hukum adat, peraturan perundang-undangan berfungsi mengganti hukum kebiasaan atau hukum adat yang tidak sesuai dengan kenyataan-kenyataan baru. Pemanfaat peraturan perundang-undangan sebagai instrumen pembaharuan hukum kebiasaan atau hukum adat sangat bermanfaat karena dalam hal-hal tertentu kedua hukum yang disebut belakangan tersebut sangat rigid terhadap perubahan.

\section{3) Fungsi Integrasi Pluralisme Sistem Hukum}

Pada saat ini, di Indonesia masih berlaku berbagai sistem hukum (empat macam sistem hukum), yaitu: "sistem hukum kontinental (Barat), sistem hukum adat, sistem hukum agama (khususnya Islam) dan sistem hukum 
Nasional". Pluralisme sistem hukum yang berlaku hingga saat ini merupakan salah satu warisan kolonial yang harus ditata kembali. Penataan kembali berbagai sistem hukum tersebut tidaklah dimaksudkan meniadakan berbagai sistem hukum- terutama sistem hukum yang hidup sebagai suatu kenyataan yang dianut dan dipertahankan dalam pergaulan masyarakat. Pembangunan sistem hukum Nasional adalah dalam rangka mengintegrasikan berbagai sistem hukum tersebut sehingga tersusun dalam suatu tatanan yang harmonis satu sama lain. Mengenai pluralisme kaidah hukum sepenuhnya digantungkan pada kebutuhan hukum masyarakat. Kaidah hukum dapat berbeda antara berbagai kelompok masyarakat, tergantung pada keadaan dan kebutuhan masyarakat yang bersangkutan.

\section{4) Fungsi Kepastian Hukum}

Kepastian hukum (rechtszekerheid, legal certainty) merupakan asas penting dalam tindakan hukum (rechtshandeling) dan penegakan hukum (handhaving, uitvoering). Telah menjadi pengetahuan umum, bahwa peraturan perundang-undangan dapat memberikan kepastian hukum yang lebih tinggi daripada hukum kebiasaan, hukum adat, atau hukum yurisprudensi. Namun perlu diketahui, kepastian hukum peratuan perundangundangan tidak semata-mata diletakkan pada bentuknya yang tertulis (geschreven, written). Untuk benar-benar menjamin kepastian hukum, perturan perundang-undangan selain harus memenuhi syarat-syarat formal, harus memenuhi syarat-syarat lain yaitu:

- Jelas dalam perumusannya (unambiguous).

- Konsisten dalam perumusannya - baik secara intern maupun ekstern. Konsisten secara intern mengandung makna bahwa dalam pertautan perundang-undangan yang sama harus terpelihara hubungan sistematik antara kaidah-kaidahnya, kebakuan susunan dan bahasa. Konsisten secara ekstern adalah adanya hubungan "harmonisasi" antara berbagai peraturan perundang-undangan.

- Penggunaan bahasa yang tepat dan mudah dimegerti. Bahasa peraturan perundangundangan haruslah bahasa yang umum dipergunakan masyarakat. Tetapi ini tidak berarti bahasa hukum tidak penting. Bahasa hukum - baikdalam artistruktur, peristilahan, atau cara penulisan tertentu harus dipergunakan secara ajeg karena merupakan bagian dari upaya menjamin kepastian hukum. Melupakan syarat-syarat di atas, peraturan perundang-undangan mungkin menjadi lebih tidak pasti dibandingkan dengan hukum kebiasaan, hukum adat, atau hukum yurisprudensi.

\section{b. Fungsi Eksternal}

Fungsi eksternal adalah keterkaitan peraturan perundang-undangan dengan lingkungan tempatnya berlaku. Fungsi eksternal ini dapat disebut sebagai fungsi sosial hukum. Dengan demikian, fungsi ini dapat juga berlaku pada hukum-hukum kebiasaan, hukum adat, atau juga hukum yuriprudensi. Bagi Indonesia, fungsi sosial ini akan lebih diperankan oleh peraturan perundang-undangan karena berbagai pertimbangan yang sudah disebutkan dimuka. Fungsi sosial ini dapat dibedakan;

\section{1). Fungsi Perubahan}

Telah lama dikalangan pendidikan hukum diperkenalkan fungsi perubahan ini yaitu hukum sebagai sarana pembaharuan (law as social engineering) Peraturan perundang-undangan diciptakan atau dibentuk untuk mendorong 


\section{$\mathrm{R}_{\text {juknaL }}^{\text {juTSVINDING }}$}

perubahan masyarakat di bidang ekonomi, sosial, maupun budaya. Masyarakat "patrilineal" atau "matrilineal" dapat didorong menuju masyarakat "parental" melalui peraturan perundang-undangan perkawinan.

\section{2). Fungsi Stabilisasi}

Peraturan perundang-undangan dapat pula berfungsi sebagai stabilisasi. Peratuan perundang-undangan di bidang pidana, di bidang ketertiban dan keamanan adalah kaidahkaidah yang terutama bertujuan menjamin stabilitas masyarakat. Kaidah stabilitas dapat pula mencakup kegiatan ekonomi, seperti pengaturan kerja, pengaturan tata cara perniagaan dan lain-lain. Demikian pula di lapangan pengawasan terhadap budaya luar, dapat pula berfungsi menstabilkan sistem sosial budaya yang telah ada.

\section{3). Fungsi Kemudahan}

Peraturan perundang-undangan dapat pula dipergunakan sebagai sarana mengatur berbagai kemudahan (fasilitas). Peraturan perundangundangan yang berisi ketentuan "insentif" seperti keringan pajak, penundaan pengenaan pajak, penyederhanaan tata cara perizinan, struktur permodalan dalam penanaman modal merupakan kaidah-kaidah kemudahan. Namun perlu diperhatikan, tidak selamanya, peraturan kemudahan akan serta merta membuahkan tujuan pemberian kemudahan. dalam penanaman modal misalnya selain kemudahan-kemudahan seperti disebutkan diatas diperlukan juga persyaratan lain seperti stabilitas politik, sarana dan prasarana ekonomi, ketenagakerjaan, dsb.

\section{Pendekatan Metodologis terhadap Pembentukan Hukum}

Sebagaimana yang dijelaskan dalam kerangka acuan bahwa pemikiran dan penerapan metodologi penelitian hukum yang berkembang di Indonesia dapat dilihat dari konsep maupun aplikasi penelitian dalam struktur diskursus. Terlihat jelas, uraian metodologi sangat dipengaruhi oleh pandangan filsafat yang dianut. Pandangan filsafat ini dapat ditelusuri dari terdapatnya "benang merah" yang secara konsisten terlihat dalam uraian teknis operasional bentuk metodologi penelitian hukum yang dianut. Secara makro dalam hukum, metode penelitian hukum normatif dan metode penelitian yuridis sosiologis dirumpunkan dalam dua kategori besar tentang cara pandang dalam metode penelitian. Dalam proses perancangan peraturan perundang-undangan, saat ini dikenal suatu metode yang dikenalkan oleh Seidman Robert P, yaitu ROCCIPI (rule, opportunity, capacity, communication, interest, process, ideology). Didalam berbagai literartur disebutkan bahwa metode ROCCIPI digunakan untuk melakukan identifikasi masalah. Identifikasi masalah dengan menggunakan ROCCIPI ini biasanya digunakan jika dalam menyusun peraturan perundang-undangan, akar masalah yang dihadapi belum sepenuhnya tergambar, sehingga diperlukan kajian dan riset yang lebih mendalam untuk menentukan akar masalah tersebut. Selain ROCCIPI dikenal pula dua metode yang berdekatan sifat dan mekanisme kerjanya, yaitu metode Fishbone dan RIA (Regulatory Impact Assessment). Metode Fishbone bekerja dengan menggunakan riset yang mendalam, segala hal diuji dalam sebuah diskusi yang panjang. Beberapa hal yang diuji adalah terkait dengan men, money, management, method, dan environment. Sejalan 
dengan Fishbone ini, ada juga RIA. RIA lebih mengutamakan pemahaman terhadap segala peraturan dibalik penyusunan peraturan yang baru. RIA biasanya digunakan sebagai jaminan untuk mendukung pembangunan dan investasi. Olehkarenaitu, pendekatan metodologiROCCIPI, RIA dan Fishbone secara konseptual harus memperhatikan kecenderungan terhadap arah perubahan hukum itu sendiri antara lain:

\section{a. Dinamika Norma Hukum responsif}

Pembaruan hukum merupakan upaya sadar, terencana dan berkesinambungan dalam kerangka membangun sistem hukum, baik segi substantif (materi muatan hukum) dan kelembagaan hukum. Hukum baik dari sisi normatif maupun praktis meliputi segala aspek kehidupan, tetapi hanya merupakan salah satu sarana untuk membentuk ketertiban. Oleh karena itu hukum harus didekati dari semua aspek kehidupan agar bersifat visioner dan beroperasi bersama dengan bidang-bidang yang lain. Dengan kata lain bahwa pembaruan hukum berupaya untuk melakukan pembebasan, baik dalam cara berpikir maupun bertindak dalam hukum, sehingga hukum mampu berperan dan berfungsi untuk mengabdi kepada manusia dan kemanusiaan. Konsekuensi logisnya, hukum akan selalu mengalami perubahan baik secara evolusioner maupun revolusioner. Hal ini berdampak pada pemaknaan terhadap aturan hukum tertulis akan selalu mengalami perubahan dengan acuan pada nilai dan moral yang lebih tinggi. Oleh karena itu, pelaksanaan dan penegakan hukum tidak boleh menjadi tawanan undang-undang. Supremasi hukum tidak bisa dimaknai sama dengan supremasi undang-undang. Perubahan paradigma hukum dan cara menerapkannya sebagaimana diuraikan di atas dimaksudkan agar hukum dan kelembagaannya dalam hal ini lembaga peradilan yang ditunjang oleh sumber daya manusia yang handal memiliki pemikiran hukum dan integritas yang tinggi akan mampu menjadi lokomotif perubahan sosial. Perhatian publik terhadap dunia hukum semakin meningkat bersamaan dengan atmosfir keterbukaan yang dinikmati oleh bangsa Indonesia sejak memasuki masa reformasi. Pertanyaan dan perdebatan kritis mengemuka dan menyentuh hingga persoalan-persoalan mendasar. Keterbukaan dan perdebatan publik semakin lama semakin menunjukkan bahwa hukum dan penegakan hukum di Indonesia perlu perubahan mendasar, tidak saja dalam praktiknya melainkan juga pada tataran konstruksi ilmu hukum dan pemaknaan terhadap hukum. Kondisi hukum dan penegakannya yang ada saat ini adalah produk dari konfigurasi politik otoritarian yang belum seluruhnya berubah. Meskipun UUD 1945 telah berubah, namun pemahaman atas hukum dan cara menerapkan hukum, terutama akademisi, legislator, penegak hukum, belum banyak mengalami perubahan. Oleh karena itu hukum di Indonesia saat ini masih memiliki watak konservatif. Kondisi hukum dan penegakan hukum di atas telah melahirkan cara penerapan hukum yang kehilangan sukma moral dan keadilan. Hukum berbelok menjadi semata-mata urusan formal-prosedural. Nilainilai etika, moral, dan rasa keadilan seringkali diabaikan. Jika ditarik ke permasalahan yang mendasar, masih terdapat ambiguitas konsepsi negara hukum yang dianut, antara rechtsstaat yang mengedepankan kepastian hukum dan konsepsi the rule of law yang menekankan pada rasa keadilan. Dalam perspektif ini, paradigma hukum dan penerapannya harus berubah yaitu munculnya pemikiran-pemikiran yang segar dan konperhensif tentang hukum 
yang bertumpu pada nilai hakiki kemanusiaan, penerapan hukum melalui kelembagaan dan aparatur hukum yang kuat, dan perhatian terhadap peranan perilaku manusia dalam hukum. Perubahan paradigma hukum dan cara menerapkan hukum tersebut diharapkan mampu menjadi lokomotif perubahan sosial, apabila ditunjang oleh kelembagaan hukum yang kuat, dan berwibawa yang dilengkapi dengan managemen dan sumber daya manusia yang handal dan integritas yang tinggi. Kelembagaan hukum yang kuat dan berwibawa tercermin pada lembaga peradilan, dan sumber daya manusia yang handal dan integritas yang tinggi tercermin pada hakim, serta manajemen tercermin pada adminsitrasi yustisial yang selalu menjaga citranya sebagai lembaga yang mandiri, bebas dari intervensi kekuasaan lainnya yang putusannya mengacu pada prinsip kepastian, keadilan, dan kemanfaatan. Lembaga peradilan yang demikian yang menjadi salah satu unsur negara hukum, sehingga lembaga peradilan yang bebas dan mandiri merupakan prinsip umum yang harus dijadikan prinsip dalam membangun dan mewujudkan negara hukum sebagaimana yang dimanatkan Pasal 1 ayat (2) dan Pasal 1 ayat (3) UUD 1945. Dalam kerangka efektifitas penegakan hukum agar hukum berwibawa, maka tidak melepaskan dari organ Negara yang secara sistemik merupakan kesatuan alur. Seperti halnya organ legislatif adalah lembaga parlemen, organ eksekutif adalah birokrasi pemerintahan, sedangkan organ judikatif adalah birokrasi aparatur penegakan hukum yang mencakup kepolisian, kejaksaan, dan pengadilan merupakan satu kesatuan rangkaian lembaga Negara yang memiliki alur kerja yang harmoni dalam rengka penegakan hukum. Semua organ harus dihubungkan dengan hirarkinya masingmasing mulai dari yang tertinggi sampai yang terendah, yaitu terkait dengan aparatur tingkat pusat, tingkat provinsi, dan tingkat kabupaten/ kota. Keseluruhan elemen, komponen, hirarki dan aspek-aspek yang bersifat sistemik dan saling berkaitan satu sama lain itulah tercakup pengertian sistem hukum yang harus dikembangkan dalam kerangka Negara Hukum Indonesia berdasarkan UUD 1945. Jika dinamika yang berkenaan dengan keseluruhan aspek, elemen, hirarki dan komponen tersebut tidak bekerja secara seimbang dan sinergis, maka hukum sebagai satu kesatuan sistem tidak dapat diharapkan terwujud sebagaimana mestinya. Saat ini masih terdapat kecenderungan memahami hukum dan pembangunan hukum secara parsial pada elemen tertentu dan bersifat sektoral. Salah satu elemen dalam sistem hukum nasional adalah kaedah aturan. Kaedah-kaedah peraturan tersebut berupa peraturan perundang-undangan yang hanya dapat dikatakan sebagai suatu tata hukum dalam sebuah sistem hukum nasional jika validitasnya dapat dilacak baik secara langsung maupun tidak langsung kepada kepada konstitusi.

\section{b. Dinamika Norma Hukum Historis}

Dalam memahami kedudukan dan fungsi suatu norma hukum, tidak dapat melepaskan pada perkembangan norma hukum itu sendiri yang secara historis meliputi, tataran teologis, tataran ontologis (filosofis), tataran positivis, dan tataran fungsional. Setiap tahapan perkembangan tersebut memiliki relasi konseptual dan ideologis, sehingga jiwa atau makna setiap rumusan norma hukum menjadi satu kesatuan system norma atau paradigm.

Normahukumdalamtataranteologismerujuk pada aliran hukum alam (natural law) sebagai salah satu aliran dalam filsafat hukum yang lahir didasarkan pada gagasan universalitas dan 
moralitas. Gagasan universalitas memberikan dasar pembenar bagi berlakunya kebebasan manusia dan pengakuan hak-hak dasar manusia dalam kehidupan negara. Demikian pula gagasan moralitas merupakan prinsip-prinsip moral yang bersifat umum dan dapat ditelaah oleh akal manusia. Kedua gagasan tersebut merupakan esensi yang tetap yang dijadikan ide dasar tentang perumusan hakekat hukum dan keadilan sebagai tujuan hukum. Mencermati kedua gagasan tersebut berarti nilai moral dan etika merupakan dasar pembentukan hukum untuk mewujudkan keadilan sebagai ide yang bersifatabadi.Konsepkeadilantidaklah dibentuk, melainkan sebagai hasil dari cara kerja alam yang merupakan puncak tertinggi dari hukum. Tetapi keadilan kemungkinan dapat terwujud atau tidak dapat diwujudkan oleh manusia, juga tergantung bagaimana hukum dirumuskan dan diaplikasikan. Dengan demikian isi hukum dalam aliran hukum alam adalah keadilan dan moral. ${ }^{22}$ Secara historis aliran hukum alam berkembang sejak abad ke 6 merupakan warisan zaman Romawi sebagai penerusan dari buku hukum Justinianus yang merupakan penulisan hukum pertama zaman Romawi. Isinya digali dari doktrin hukum zaman Yunani yang digali dari pemikiran Cicero. Menurut Cicero manusia merupakan masyarakat alam raya. Hukum hakekatnya merupakan ekspresi dari hakekat umum manusia yang bersifat universal. Dalam perkembangannya pemikiran ini oleh /mmanual Kant dirumuskan bahwa hukum alam sebagai hukum yang bersumber pada katagorische imperative. Konsep dasar dari pemikiran Kant adalah bahwa hukum merupakan motivasi tindakan manusia. Motif tindakan manusia dibedakan dalam dua hal yaitu, jika motif tindakan manusia bersifat intern (untuk dirinya sendiri) dikatagorikan moral, tetapi jika bersifat ekstern dikatagorikan hukum. Tindakan bersifat ekstern dikatagorikan sebagai hukum karena tindakantersebut dapat berpengaruh atau diikuti oleh orang lain. Dalam hubungannya dengan agama, maka prinsip agama sarat dengan nilai moral dan keadilan dapat dipahami sebagai prinsip-prinsip yang bersesuian dengan asas dan isi hukum alam. Oleh karena itu, pluralisme hukum sangat dimungkinkan dalam masyarakat yang bercorak majemuk seperti Indonesia, dan agama dapat ditempatkan sebagai sumber atau norma dasar yang menjadi rujukan dalam perumusan hukum. Secara politis dan normatif hal tersebut pernah diberlakukan di Indonesia yaitu, pertama pada zaman pemerintahan Hindia Belanda dan yang kedua pada masa 
pemerintahan negara kesatuan RI yang tertuang baik dalam Piagam Jakarta maupun dalam Pasal 29 UUD 1945. Secara historis pemikiran tersebut dapat ditelusuri terhadap kebijakan hukum yang pernah diberlakukan di Indonesia. Pemerintah Kolonial Belanda pernah menetapkan Reglement op het beleid der Regeering van Nederlands Indie, disingkat Regeering Reglement (RR) yang diundangkan dalam Staatsblad 1882/152. ${ }^{23}$ Pasal 75 ayat (3) RR menegaskan bahwa bagi Bumi putera diberlakukan hukum agama. Keputusan politik (politik hukum) yang dianut itu merupakan pengaruh teori yang dikembangkan oleh Lodewijk Willem Chritian van den Berg yaitu, teori reception in complex. Teori ini berpendirian bahwa norma hukum didasarkan pada norma agama. ${ }^{24}$ Dalam perkembangan politik hukum, teori receptio in complexu oleh Snouck Hurgrounye dan van Vollehhoven dianggap tidak tepat di samping tidak menguntungkan pemerintah kolonial. Sebagai antinomi teori receptio in complexu dikembangkan teori receptie. Teori ini menyatakan bahwa hukum yang berlaku pada masyarakat bumiputera adalah hukum adat bukan hukum agama. Hukum Agama dapat berlaku jika telah diterima (diresipir) oleh hukum adat. Pendapat Snouck maupun van Vollenhoven dijadikan dasar perumusan politik hukum pemerintah kolonial yang dituangkan dalam Wet op de Staatsinrechting van Nederlandsch Indie atau Indische Staatsregeling (IS) Stbl. 1929:212. Persoalan kemajemukan hukum dengan menempatkan agama sebagai dasar perumusan hukum di Indonesia juga berkembang saat sidang BPUPKI. Hasil rumusan BPUPKI dikenal dengan Piagam Jakarta yang menempatkan agama sebagai dasar berpijak dalam menata kehidupan masyarakat terutama masyarakat yang bergama Islam.

Pada tataran ontologis, maka norma hukum memiliki sisi dinamis karena hukum menjadi obyek kajian/studi yang kritis yang melahirkan berbagai teori, aliran dan paradigm hukum. Dalam perspektif ini, maka norma hukum tataran paradigmatic dan memiliki akar yang kuat atas prinsip-prinsip atau asas-asas, tujuan, dan fungsi hukum dalam menata kehidupan masyarakat dan Negara. Misalnya perkembangan pemikiran hukum pada abad pertengahan yang

23 R. Soepomo, Sejarah Politik Hukum Adat, Jilid I (Jakarta: Pradnya Paramita, 1982), hlm. 30. Lihat Soepomo dalam Moh. Yamin, Naskah Persiapan Undang-Undang Dasar 1945,(Jakarta: Yayasan Prapanca, 1959), hal. 109 yang dalam Sidang BPUPKI tanggal 15 Juli 1945 menyatakan bahwa Indische Staatsregeling pengganti RR sebagai Undang-Undang Dasar Belanda. Pasal 75 ayat (3) RR menjelaskan bahwa Oleh Hakim Indonesia itu hendaklah diperlakukan undang-undang agama (godsdienstige wetten) dan kebiasaan penduduk Indonesia itu. Pasal 78 ayat (2) RR menegaskan bahwa "Dalam hal terjadi perkara perdata antara sesama orang Indonesia itu, atau dengan mereka yang dipersamakan dengan mereka, maka mereka tunduk kepada putusan hakim agama atau kepala masyarakat mereka menurut undang-undang agama (godsdientige wetten) atau ketentuan-ketentuan lama mereka". Bandingkan Sayuti Thalib yang berpendapat bahwa kemajemukan hukum maupun kelembagaan hukum yang dipilih oleh pemerintah kolonial Belanda bukan kemajemukan dalam arti pembidangan hukum, akan tetapi dalam arti politik hukum yakni menyangkut substansi hukum yang membedakan derajat hukum yang satu dengan lainnya. Pembedaan derajat yang menempatkan hukum Eropa (Belanda) lebih tinggi derajatnya dibanding dengan hukum lokal (pribumi) menunjukkan sifat arogan pemerintahan Belanda yang menempatkan masyarakat Belanda derajatnya lebih tinggi dari masyarakat Indonesia (pribumi). Sayuti Thalib, Politik Hukum Baru - Mengenai Kedudukan dan Peranan Hukum Adat dan Hukum Islam dalam Pembinaan Hukum Nasional, Cet. Pertama (Bandung : Binacipta, 1987), hlm. 63.

24 Sayuti Thalib, Receptio A Contrario-Hubungan Hukum Adat dengan Hukum Islam, (Jakarta: Bina Aksara, 1985), hlm. 7. 
menunjukkan intensifnya kajian-kajian metafisis yang saat itu sangat dominan ditinggalkan dan dipandang sebagai biang keladi ketertinggalan peradaban manusia, maka munculah Ilmuilmu alam yang lebih dapat memberikan jaminan kepastian dan dapat diprediksikan. Melalui rasionalisme dan empirisisme Ilmuilmu alam berusaha mengembangkan konsep teori murni. Dengan mengambil sikap teoritis murni, Ilmu-ilmu alam dapat membebaskan diri dari dorongan kepentingan-kepentingan manusiawi (subyektif) sehingga dengan jalan ini mereka mendapatkan kebenaran obyektif. Perkembangan lainnya adalah munculnya konsep hukum otonom. Dengan munculnya hukum otonom, tertib hukum menjadi sumber daya untuk menjinakkan represi. Secara historis, perkembangan tersebut dapat disebut sebagai 'Rule of Law' (pemerintahan berdasarkan hokum). Rule of Law mengandung arti lebih dari sekadar eksistensi hokum. la merujuk pada sebuah aspirasi hukum dan politik, penciptaan "sebuah pemerintahan berdasarkan hukum dan bukan berdasarkan orang-orang." Dalam pemahaman seperti itu, rule of law akan lahir ketika institusi-institusi hukum mendapatkan cukup otoritas independen untuk memaksakan standar-standar pengendalian dalam pelaksanaan kekuasaan pemerintahan. Rule of law dipahami secara lebih baik sebagai sebuah sistem kelembagaan tersendiri daripada sebagai sebuah cita-cita abstrak. Karakter utama dari sistem ini adalah terbentuknya institusiinstitusi hukum yang terspesialisasi dan relatif otonom yang mengklaim suatu supremasi yang memenuhi syarat di dalam bidang-bidang kompetensi yang ditentukan. ${ }^{25}$ Dengan risiko menyumbang jargon baru, kami menyebut sistem ini sebagai rezim hukum otonorn. ${ }^{26}$ Frase 'hukum otonom' ini tidak dimaksudkan untuk menggambarkan sebuah otonomi yang aman dan sempurna. Frase ini justru mengemukakan bahwa, pada tahap ini, konsolidasi dan dipertahankannya otonomi kelembagaan merupakan pusat perhatian para pejabat hukum. Frase tersebut menunjuk pada kelemahankelemahan dan juga keberhasilan-keberhasilan dari rule of law. Keterbatasan-keterbatasan hukum otonom muncul karena terlalu banyak energi digunakan untuk keperluan menjaga integritas kelembagaan dengan mengabaikan tujuan-tujuan hukum lainnya.

Dalam tataran ini norma hukum memiliki bentuknya dan mengikat kepada masyarakat serta Negara memiliki otoritas menegakkannya. Proses pembentukannya sebagai naskah hukum melalui legitimasi politik yakni melalui keputusan lembaga politik yang memiliki kewenangan untuk memutus dan menetapkan norma hukum dengan bentuk tertentu. Oleh 


\section{$\mathrm{R}_{\text {juknaL }}^{\text {juTSVINDING }}$}

karena itu, ketika norma hukum memperoleh bentuk dan legitimasi kekuasaan memaksa, maka seluruh norma hukum yang sebelumnya masih dalam tartan teologis dan paradigmatic menjelma sebagai kekuatan yang memiliki otorisasi memaksa (dwingen recht) dan mengikat (binding).

Dalam tataran ini norma hukum telah menjadi saripati dari setiap gerak dan langkah individu, kelompok masyarakat dan Negara. Artinya, hukum telah melembaga dalam kehidupan masyarakat dan Negara, sehingga norma hukum menjadi sumber rujukan, penuntun, dan sekaligus sebagai instrument dari tata kehidupan individual dan kolektif. Pada tataran inilah tujuan hukum menjelma menjadi budaya hukum masyarakat yang tercermin dalam aspek keadilannya, aspek kepastiannya karena mampu mewujudkan tertib social yang dinamis, dan aspek kemanfaatannya karena dijadikan penuntun langkah masyarakat.

Negara hukum (Rechtsstaat atau The Rule of Law) adalah konsep negara yang diidealkan oleh para pendiri bangsa yang membahas dan merumuskan UUD 1945, sebagaimana kemudian dituangkan dalam penjelasan UUD 1945 sebelum perubahan. Penegasan sebagai negara hukum dikuatkan dalam UUD 1945 setelah perubahan pada Pasal 1 ayat (3) yang berbunyi "Negara Indonesia adalah Negara Hukum". ${ }^{27}$ Sebagai sebuah negara hukum, maka hukum harus dipahami dan dikembangkan sebagai satu kesatuan sistem. Sebagai sebuah sistem, hukum terdiri dari elemen-elemen (1) kelembagaan (institutional), (2) kaedah aturan (instrumental), (3) perilaku para subyek hukum yang menyandang hak dan kewajiban yang ditentukan oleh norma aturan itu (elemen subyektif dan kultural). Ketiga elemen sistem hukum tersebut mencakup (a) kegiatan pembuatan hukum (law making), (b) kegiatan pelaksanaan hukum atau penerapan hukum (Iaw administrating), dan (c) kegiatan peradilan atas pelanggaran hukum (law adjudicating) atau yang biasa disebut dengan penegakkan hukum dalam arti sempit (law enforcement). Selain kegiatankegiatan tersebut di atas, terdapat beberapa kegiatan lain yang sering dilupakan, yaitu (d) pemasyarakatan dan pendidikan hukum (law socialization and law education) secara luas dan juga meliputi (e) pengelolaan informasi hukum (law information management). Kedua kegiatan tersebut merupakan kegiatan penunjang yang semakin penting kontribusinya dalam sistem hukum nasional. Kelima kegiatan dalam sistem hukum tersebut biasanya dibagi ke dalam tiga wilayah fungsi kekuasaan negara, yaitu (i) fungsi legislasi dan regulasi, (ii) fungsi eksekutif dan administratif, serta (iii) fungsi judikatif atau judisial. ${ }^{28}$ Organ legislatif adalah lembaga parlemen, organ eksekutif adalah birokrasi pemerintahan, sedangkan organ judikatif adalah birokrasi aparatur penegakan hukum yang mencakup kepolisian, kejaksaan, dan pengadilan. Semua organ harus dihubungkan dengan hirarkinya masing-masing mulai dari yang tertinggi hingga terendah, yaitu terkait dengan aparatur tingkat pusat, tingkat provinsi, dan tingkat kabupaten/kota. Keseluruhan elemen, komponen, hirarki dan aspek-aspek

27 Pasal 1 ayat (3) ini merupakan hasil Perubahan Keempat UUD 1945.

28 Montesquieu, The Spirit of the laws, Translated by Thomas Nugent, (London: G. Bell \& Sons, Ltd, 1914), Part XI, Chapter 67. 
yang bersifat sistemik dan saling berkaitan satu sama lain itulah tercakup pengertian sistem hukum yang harus dikembangkan dalam kerangka Negara Hukum Indonesia berdasarkan UUD 1945. Jika dinamika yang berkenaan dengan keseluruhan aspek, elemen, hirarki dan komponen tersebut tidak bekerja secara seimbang dan sinergis, maka hukum sebagai satu kesatuan sistem tidak dapat diharapkan terwujud sebagaimana mestinya. Saat ini masih terdapat kecenderungan memahami hukum dan pembangunan hukum secara parsial pada elemen tertentu dan bersifat sektoral. Salah satu elemen dalam sistem hukum nasional adalah kaedah aturan. Kaedah-kaedah peraturan tersebut berupa peraturan perundangundangan yang hanya dapat dikatakan sebagai suatu tata hukum dalam sebuah sistem hukum nasional jika validitasnya dapat dilacak baik secara langsung maupun tidak langsung kepada kepada konstitusi- Tata hukum, sebagai personifikasi negara, merupakan suatu hirarki peraturan perundang-undangan yang memiliki level berbeda. Kesatuan peraturan perundangundangan ini disusun oleh fakta bahwa pembuatan peraturan perundang-undangan yang lebih rendah ditentukan oleh peraturan perundang-undangan lain yang lebih tinggi. Peraturan perundang-undangan di Indonesia sebagai suatu tata hukum nasional juga disusun secara hierarkis. Hubungan hierarkis tersebut terjalin secara utuh dan berpuncak pada konstitusi yang dalam negara hukum dikenal sebagai prinsip supremasi konstitusi. Sebagai konsekuensi dari supremasi konstitusi dan hierarki perundang-undangan dalam suatu sistem hukum, maka perubahan konstitusi mengharuskan adanya perubahan terhadap perundang-undangan dalam sistem hukum tersebut, serta pelaksanaannya oleh pihak yang berwenang. ${ }^{29}$ Demikian pula halnya dengan perubahan UUD 1945 yang cukup mendasar dan meliputi hampir keseluruhan ketentuan yang terdapat di dalamnya, harus diikuti dengan perubahan perundang-undangan yang berada di bawahnya dan pelaksanaannya oleh organ yang berwenang. Ketentuan-ketentuan perundangundangan yang telah ada yang bersumber pada ketentuan tertentu dalam UUD 1945 sebelum perubahan harus dilihat kembali kesesuaiannya dengan ketentuan hasil perubahan UUD 1945. Segera setelah agenda constitutional reform (pembaruan konstitusi) berhasil dilakukan, kita perlu melanjutkan dengan agenda legal reform (pembentukan dan pembaruan hukum). Jika kita mencermati ketentuan-ketentuan dalam UUD 1945 setelah empat kali dirubah, terdapat 22 butir ketentuan yang menyatakan "diatur dengan undang-undang" atau"diatur lebih lanjut dengan undang-undang", 11 butir ketentuan yang menyatakan "diatur dalam undang-undang" atau "diatur lebih lanjut dalam undang-undang", dan 6 butir ketentuan menyatakan "ditetapkan dengan undang-undang. Ketentuan-ketentuan tersebut jelas mengamanatkan perlunya dilakukan pembaruan hukum sebagai bentuk pelaksanaan UUD 1945. Bidang-bidang hukum yangmemerlukan pembentukan dan pembaruan tersebut dapat dikelompokkan menurut bidangbidang yang dibutuhkan, misalnya; Bidang

Hukum dapat dikategorikan menjadi empat kelompok pengertian hukum dilihat dari wilayah pembuatan dan pembentukan hukum, yaitu Hukum Negara (The State's Law), Hukum Adat (The People's Law), Doktrin (The Professor's Law), dan hukum praktek (The Professional's Law). Lihat Jimly Asshiddiqie, Hukum Tata Negara dan Pilar-Pilar Demokrasi, (Jakarta; Konstitusi Press, 2005), hlm. 4. 


\section{$\mathrm{R}_{\text {juknaL }}^{\text {juTSVINDING }}$ \\ Media Pembinaan Hukum Nasional}

politik dan pemerintahan; Bidang ekonomi dan dunia usaha; Bidang kesejahteraan sosial dan budaya; dan Bidang penataan sistem dan aparatur hukum. Sebagai suatu kesatuan sistem hukum, upaya perubahan perundang-undangan untuk menyesuaikan dengan perubahan UUD 1945 adalah bagian yang tidak terpisahkan dari pembangunan hukum nasional secara keseluruhan. Karena itu, perubahan berbagai perundang-undangan sebaiknya dilakukan secara terencana dan partisipatif dalam program legislasi nasional sekaligus bentuk legislatif review. Program legislasi nasional harus disusun pertama dan utamanya adalah untuk melaksanakan ketentuan dalam UUD 1945. Berdasarkan ketentuan UUD 1945 dapat dielaborasi perundang-undangan yang harus dibuat dalam program legislasi nasional baik di bidang politik, ekonomi, maupun sosial. Di samping itu masyarakat juga dapat mengajukan permohonan constitutional review kepada Mahkamah Konstitusi terhadap Undang-Undang yang dianggap merugikan hak konstitusionalnya dalam UUD 1945 yang telah diubah. Masyarakat juga dapat mengajukan judicial review kepada Mahkamah Agung terhadap peraturan perundang-undangan di bawah Undang-Undang yang dianggap bertentangan dengan UndangUndang.

\section{E. Penutup}

\section{Kesimpulan}

Fungsi Peraturan Perundang-undangan dapat dipilah menjadi Fungsi Internal dan fungsi eksternal. Pertama, Fungsi internal terdiri dari fungsi penciptaan hukum, fungsi pembaharuan hukum, fungsi integrasi pluralisme sistem hukum, dan fungsi kepastian hukum. Fungsi penciptaan hukum melahirkan sistem kaidah hukumyang berlaku umum dilakukan atau terjadi melalui beberapa cara yaitu melalui putusan hakim (yurisprudensi), kebiasaan yang tumbuh sebagai praktek dalam kehidupan masyarakat atau negara, dan peraturan perundangundangan sebagai keputusan tertulis pejabat atau lingkungan jabatan yang berwenang yang berlaku secara umum. Sedangkan Fungsi Pembaharuan Hukum terhadap peraturan perundang-undangan antara lain dalam rangka mengganti peraturan perundang-undangan dari masa pemerintahan Hindia Belanda. Tidak pula kalah pentingnya memperbaharui peraturan perundang-undangan nasional (dibuat setelah kemerdekaan) yang tidak sesuai lagi dengan kebutuhan dan perkembangan baru. Fungsi integrasi pluralisme sistem hukum berupaya mengintegrasikan berbagai sistem hukum (empat macam sistem hukum), yaitu: sistem hukum kontinental (Barat), sistem hukum adat, sistem hukum agama (khususnya Islam) dan sistem hukum Nasional. Sedangkan Fungsi Kepastian Hukum menjadikan peraturan perundang-undangan dapat memberikan kepastian hukum yang lebih tinggi daripada hukum kebiasaan, hukum adat, atau hukum yurisprudensi. Namun perlu diketahui, kepastian hukum peratuan perundang-undangan tidak semata-mata diletakkan pada bentuknya yang tertulis (geschreven, written). Kedua, fungsi eksternal adalah keterkaitan peraturan perundang-undangan dengan lingkungan tempatnya berlaku. Fungsi eksternal ini dapat disebut sebagai fungsi sosial hukum. Dengan demikian, fungsi ini dapat juga berlaku pada hukum-hukum kebiasaan, hukum adat, atau juga hukum yuriprudensi.

Dalam melakukan pembangunan hukum melalui peraturan perundang-undangan, pendekatan metodologi yang dipilih yang sangat dipengaruhi oleh pandangan filsafat 
yang dianut. Pandangan filsafat ini dapat ditelusuri dari terdapatnya "benang merah" yang secara konsisten terlihat dalam uraian teknis operasional bentuk metodologi penelitian hukum yang dianut. Secara makro dalam hukum, metode penelitian hukum normatif dan metode penelitian yuridis sosiologis dirumpunkan dalam dua kategori besar tentang cara pandang dalam metode penelitian. Dalam proses perancangan peraturan perundang-undangan, saat ini dikenal suatu metode yang dikenalkan oleh Seidman Robert P, yaitu ROCCIPI (rule, opportunity, capacity, communication, interest, process, ideology); metode Fishbone dan RIA (Regulatory Impact Assessment).

Suatu pembentukan hukum memiliki pengaruh bahkan menjadi elemen penting dalam pembaruan hukum, apabila pembentukan hukum ditempatkan sebagai upaya sadar dan sungguh-sungguh untuk menempatkan system hukum bagian penting dalam sistem kenegaraan dan sistem sosial. Konsep-konsep yang abstrak, seperti kewajiban hukum, sebenarnya berbicara mengenai hal-hal yang menciptakan perbedaan dalam pemahaman mengenai hukum dan tentang bagaimana hukum itu digunakan. Sudut Pandang filosofis (seperti kritik positivisme) dan persoalan-persoalan analitis yang sulit dijawab (seperti perbedaan antara aturan dan prinsip) merupakan metode yang tidak bisa ditawar lagi untuk memeriksa persoalan-persoalan yang mengelilingi tertib hukum. Jadi, teori hukum tidaklah buta terhadap konsekuensi sosial dan tidak Pula kebal dari pengaruh sosial. Tempat di mana harus mencari landasan-landasan hukum, pengertian yang dibuat tentang proses hukum, dan menempatkan hukum dalam masyarakat, sangat mempengaruhi bentuk komunitas politik dan jangkauan aspirasi-aspirasi sosial.

\section{Saran}

Dalam pembentukan hukum dalam perspektif pembaharuan hukum, di samping harus memperhatikan aspek metodologis, juga harus merujuk dan meletakkan norma hukum dalam kesatuan harmoni vertikal dengan aspek teologis, ontologis, positivistik dan aspek fungsional dari suatu norma hukum.

pendekatan metodologi ROCCIPI, RIA dan Fishbone secara konseptual harus memperhatikan kecenderungan terhadap arah perubahan hukum itu sendiri antara lain: dinamika norma hukum responsive dan dinamika norma hukum historis.

\section{DAFTAR PUSTAKA}

\section{Buku}

Asshiddiqie, Jimly, Konstitusi dan Konstitusionalisme Indonesia, (Jakarta: Mahmakah Konstitusi RI dan Pusat Studi Hukum Tata Negara Fakultas Hukum UI, 2004).

Azhary, Negara Hukum Indonesia - Analisis Yuridis Normatif tentang Unsur-unsurnya, Cet. Pertama, (Jakarta : UI-Press, 1995).

Cotterell, Roger, The Sociology of Law: An Introduction, (London: Butterworths, 1992).

Friedman, Legal Theory, Fifth Edition (London: Stevens \& Sons Limited, 1967).

Hoesein, Zainal Arifin, Yudicial Review di Mahkamah Agung, Tiga Dekade Pengujian Peraturan Perundang-undangan, (Jakarta: PT. Raja Grafindo Persada, 2009)

Kelsen, Hans, General Theory of Law and State, translated by: Anders Wedberg, (New York; Russell \& Russell, 1961).

Manan, Bagir, Menegakkan Hukum Suatu Pencarian, Cetakan Pertama, (Jakarta: Asosiasi Advokat Indonesia, 2009).

Martosoewignjo, Sri Soemantri, Pengantar Perbandingan Antar Hukum Tata Negara, Ed. Kedua, (Jakarta: CV Rajawali, 1981).

Montesquieu, The Spirit of the laws, Translated by Thomas Nugent, (London: G. Bell \& Sons, Ltd, 1914).

Noer, Deliar, Partisipasi Dalam Pembangunan, (Kuala Lumpur: Angkatan Belia Islam Malaysia, 1977). 


\section{REECHTSVINDING}

N. Schiff, David, Hukum Sebagai Suatu Fenomena Sosial, dalam Adam Podgorecki dan Christopher J. Welan(editor), Pendekatan Sosiologis Terhadap Hukum, terj. dari, Sociological Approaches To Law, (Jakarta: Bina Aksara, 1999).

Pound, Roscoe, An Introduction to the Philosophy of Law - with a new introduction by Marshal L. De Rosa, (New Brunswick (USA) and London (UK): 1999 - Originally published in 1922 by Yale University Press.

Rasjidi, Lili dan IB Wyasa Putra, Hukum Sebagai Suatu Sistem, Cet. Pertama (Bandung: PT. Remaja Rosdakarya, 1993)

Rawl, John, Teori Keadilan, Dasar-DasarFilsafat Politik untuk Mewujudkan Kesejahteraan Sosial dalam Negara, Yogyakarta: Pustaka Pelajar, 2006, , terjemahan A Theory of Justice, (Cumbride, Massachusett: Harvard University Press, 1995).

Rommen, Heinrich A. The Natural Law - A Study in Legal and Social History and Philosophy, (Indianapolis: Liberty Fund, 1998).

Seno Adji, Oemar, Peradilan Bebas Negara Hukum, (Jakarta : Erlangga, 1980)

Soepomo, R., Sejarah Politik Hukum Adat, Jilid I: (Jakarta: Pradnya Paramita, 1982).

Strong, CF. , Modern Political Constitutions - An Introduction to the Comparative Study of their History and Existing Forms, 8th revised and enlarged edition (London: Sidgwick \& Jackson Limited, 1972). 